\title{
Importance of training in ensuring the hygiene-sanitary quality of lettuce salads served in nursery schools
}

\section{Importância da capacitação no controle da qualidade higiênico-sanitária em saladas de alface servidas em creches}

\author{
Melissa Schirmer ${ }^{1}$, Nágela Farias Magave Picanço ${ }^{1}$ \\ Rozilaine Aparecida Pelegrine Gomes de Faria ${ }^{1 *}$ (D)
}

${ }^{1}$ Instituto Federal de Educação, Ciência e Tecnologia de Mato Grosso (IFMT), Departamento de Ciência e Tecnologia de Alimentos, Cuiabá/MT - Brasil

*Corresponding Author: Rozilaine Aparecida Pelegrine Gomes de Faria, Instituto Federal de Educação, Ciência e Tecnologia de Mato Grosso (IFMT), Departamento de Ciência e Tecnologia de Alimentos, Avenida Juliano Costa Marques, s/n, Bairro Bela Vista, CEP: 78050-560, Cuiabá/MT - Brasil, e-mail: rozilaine.faria@blv.ifmt.edu.br

Cite as: Schirmer, M., Picanço, N. F. M., \& Faria, R. A. P. G. (2019). Importance of training in ensuring the hygienesanitary quality of lettuce salads served in nursery schools. Brazilian Journal of Food Technology, 22, e2018282. https://doi.org/10.1590/1981-6723.28218

\begin{abstract}
The food provided in nursery schools should meet the sanitary and nutritional requirements needed to promote a child's intellectual and physical health. Therefore, training of the School Nutrition Technicians (SNT) in good food handling practices is essential to ensure the safety of the foods prepared. This study was aimed at evaluating the microbiological quality of lettuce salads consumed by children in public nursery schools in the municipality of Cuiabá, Mato Grosso, Brazil. The lettuce salad samples were collected in two distinct phases: before and after training of the SNTs in good food handling practices by the nutritionists of the school meals program of the municipality of Cuiabá, according to the school calendar routine. Thirty fresh (in natura) lettuce samples that had not been sanitized (representing samples obtained from the supplier) were collected for the detection of Salmonella spp. and 240 prepared lettuce salad samples (salads ready for consumption), for the detection of Salmonella spp. and the heat-tolerant coliform count. The genus Salmonella was not detected in either of the phases of the study. However, prior to training, $54 \%$ of the lettuce salad batches were contaminated with heat-tolerant coliforms, but after training $100 \%$ of the batches were considered to be in satisfactory sanitary conditions. In conclusion, offering training courses on good food handling practices to food handlers in school meals units was capable of reducing contamination.
\end{abstract}

Keywords: Microbiological quality; School meals; Good food handling practices; Salmonella spp.; Heat-tolerant coliforms; Microbiological contamination.

\section{Resumo}

A alimentação servida nas creches deve atender à qualidade higiênico-sanitária e nutricional, para promover a saúde física e intelectual das crianças. Portanto, a capacitação das técnicas em nutrição escolar nas Boas Práticas de Manipulação é fundamental para assegurar a inocuidade dos alimentos preparados. Este trabalho teve como 
objetivo avaliar a qualidade microbiológica de saladas de alface consumidas pelos escolares de creches públicas do município de Cuiabá, Mato Grosso. As coletas foram realizadas e as amostras analisadas em duas fases distintas: antes e após a capacitação das técnicas em nutrição escolar nas Boas Práticas de Manipulação, realizada pelos nutricionistas da Coordenadoria de Alimentação Escolar do município de Cuiabá, conforme rotina do calendário escolar. Foram coletadas 30 amostras in natura (aquelas que não passaram pelo processo de higienização, representando a amostra proveniente do fornecedor), para a Pesquisa de Salmonella spp., e 240 preparadas (saladas prontas para o consumo), para a Pesquisa de Salmonella spp. e contagem de coliformes termotolerantes. O gênero Salmonella não foi evidenciado e observou-se que, antes da capacitação, houve contaminação em $54 \%$ dos lotes de saladas de alface por coliformes termotolerantes e que, após a capacitação, $100 \%$ dos lotes foram considerados sanitariamente satisfatórios, comprovando que a capacitação e a correção na higienização e nos procedimentos operacionais das técnicas em nutrição escolar foram capazes de reduzir a contaminação.

Palavras-chave: Qualidade microbiológica; Alimentação escolar; Boas práticas; Salmonella spp.; Coliformes termotolerantes; Contaminação microbiológica.

\section{Introduction}

In Brazil, nursery education is the first stage of basic education, with the aim of the integrated physical, psychological, intellectual and social development of children of up to six years of age, thereby complementing the roles played by families and communities. Nursery education is provided in nursery schools or their equivalents for children of up to three years of age, and in preschools for children of four to six years of age (Brasil, 1996).

One of the responsibilities of nursery schools is feeding the children. This is considered as an approach to the achievement of food and nutrition safety, which is defined as the right of all people to the regular and permanent access to food of good quality in sufficient quantities, without compromising the access to other essential necessities. This is based on health-promoting food practices that respect cultural diversity, and are environmentally, culturally, economically and socially sustainable (Brasil, 2006). The responsibility to serve food with the guarantee of quality is shared by the government at all its different levels (Elias et al., 2018).

The food served to children must meet the necessary sanitary and nutritional requirements, so that the children can develop intellectually and physically. However, the criteria for determining food quality may vary between different consumers and food handlers (Egan et al., 2007; Öz et al., 2014).

In the school environment, it is important to introduce good hygiene habits amongst the school children, such as the proper washing of hands before eating. However, if the food handlers do not adhere to hygienic practices before preparing the school meals, contamination can occur. Furthermore, the concept of food quality and food safety has different interpretations amongst consumers (Röhr et al., 2005), and considering that food handlers are potential consumers, the adoption of good handling practices becomes vitally important to ensure the safety of the food served to school children.

The Brazilian National School Meals Program (PNAE) is considered to be one of the main school meals programs in the world and is the only one providing a global service. With the aim of meeting the nutritional needs of school children during the academic year, it contributes to biopsychosocial growth and development, and improvement in the learning and academic performance of the students, as well as promoting the development of healthy eating habits (Brasil, 2009; Brasil, 2013; Fundo Nacional do Desenvolvimento da Educação, 2014).

According to the report of the Brazilian National Fund for Educational Development (Fundo Nacional do Desenvolvimento da Educação, 2015), the school meals program of the municipality of Cuiabá, the capital city of the State of Mato Grosso, receives donations to enrol students from municipal nursery schools or nursery schools run by charitable trusts and community organizations that receive assistance via donations. 
Although the aims of the PNAE are relevant with respect to nutrition (Raphaelli et al., 2017), many of the Food and Nutrition Units (FNU) do not provide adequate facilities for meal preparation. The school should ensure the nutritional quality and safety of the food prepared as well as the compliance of the food preparation with the sanitary requirements in order to protect the school children and maintain their health (Brasil, 2006; Cardoso et al., 2010; Elias et al., 2018).

Food served in schools and nursery schools may carry Foodborne Diseases (FBD) if not handled according to good food handling practices, and food handlers should be trained in order to ensure the high quality and safety of prepared foods (Oliveira et al., 2008; Veiros et al., 2009; Cardoso et al., 2010; Stedefeldt et al., 2013).

Fresh vegetables can carry disease when handled without good food handling practices (Falomir et al., 2010), especially lettuce, and have been identified as important vehicles of common public health pathogens (Santana et al., 2009).

The quality control and safety check of food served to school children can be done by way of microbiological analysis of the equipment, facilities, utensils, raw materials and prepared foods, serving as a basis for the evaluation of the hygienic and sanitary conditions under which the procedures were carried out by the food handlers (Santana et al., 2009; Cunha et al., 2012; Stedefeldt et al., 2013; Cho \& Bae, 2016; Neitzke et al., 2017).

There are several varieties of salads, mostly based on raw vegetables such as tomato, radish and cucumber, as well as leafy greens such as lettuce, watercress and chicory. In Brazil, lettuce (Lactuca sativa) is the most popular leafy vegetable used in salads, and there are a variety of cultivars. It is cultivated in all regions of Brazil (Henz \& Suinaga, 2009), and its low calorific value makes it suitable for consumption in several diets, usually in the raw form, leading to the development of intestinal diseases (Santana et al., 2006) when inadequately sanitized. The use of a sanitizing agent is necessary to reduce the microbial load, since lettuce is consumed raw, and may be a vehicle for the spread of pathogens, such as Escherichia coli (Santos et al., 2010).

Nowadays, people are choosing to eat fresh vegetables. In order to encourage healthy habits, one must stimulate them in childhood, and hence it is crucial that primary schools ensure the quality of the fresh vegetables they offer to the children. In order to guarantee the maintenance of such quality, food handlers should frequently be encouraged and trained to prepared safe foods. It is possible that the food offered to schoolchildren in infancy does not meet the requirements of the legislation, based on the absence of pathogenic microorganisms, or that the microbiological quality of the food is not in accordance with current legislation. Thus, the aim of this study was to compare the microbiological quality of lettuce salads served to schoolchildren in public nursery schools in the municipality of Cuiabá, Mato Grosso, Brazil, before and after training the school nutrition technicians according to the good handling practices for food preparation.

\section{Material and methods}

This study was carried out in eight municipal nursery schools (denominated $\mathrm{C} 1$ to $\mathrm{C} 8$ ) located in the urban area of Cuiabá, Mato Grosso, Brazil and supervised by the PNAE .

The study involved sample collection in two distinct phases: before and after the training of the people responsible for handling the food served to the schoolchildren. They were trained in techniques for nutrition according to the good practices for food handling.

\subsection{Phase 1 - Before Training (BT)}

The nursery schools selected had the following characteristics in common: lack of facilities involved in the production and distribution of whole milk and formulae for infants, location in the urban area of the city, and ownership of individual headquarters. The nursery schools that participated in the study were in the 
eastern region occupying the central urban area of the municipality of Cuiabá $\left(-15^{\circ} 35^{\prime} 46^{\prime \prime} \mathrm{W}\right.$ and 56L05'48"S). The municipality consists of 111 residential locations (regular settlements, clandestine settlements, informal settlements, households and condominiums), distributed over 49 neighbourhoods and a large urban area. The Eastern Region has $28 \%$ of the urban municipal nursery schools and $26 \%$ of the nursery school students of Cuiabá, totalling 1767 students (Cuiabá, 2010; Fundo Nacional do Desenvolvimento da Educação, 2015).

The samples were classified as in natura samples (lettuce leaves that had not undergone the sanitation process, representing the samples obtained from the supplier) and samples prepared for consumption (10 large lettuce leaves weighing approximately $25 \mathrm{~g}$, obtained from salads prepared for consumption by the children in nursery schools). Five in natura (control) lettuce samples from the supplier batch distributed to the nursery schools to prepare the salads, were randomly collected in triplicate before training (BT) and after training (AT), totalling 15 in natura samples for each phase. The samples were collected at the distribution centre of the school meals program of the municipality of Cuiabá on a weekly basis on Monday mornings, according to the delivery schedule of the supplier in order to fulfil the menu schedule.

\subsection{Phase 2 - After Training (AT)}

The training was provided by nutritionists of the school meals program of the city of Cuiabá, according to the schedule as per school calendar. Training was carried out one week after collection of the BT samples.

The training addressed the right procedure to be followed at all stages of food preparation, including acquisition of the raw material, washing and disinfection of the food, facilities and utensils, packaging, refrigeration, handling and serving of the food to the children. The training included the use of protective work uniform and hygienic habits that should be developed during work.

\subsection{Collection of samples for analyses}

From the batch from which the in natura samples were taken, the School Nutrition Technicians (SNT) prepared the lettuce leaves to be served to the students. Five samples ( $25 \mathrm{~g}$ each) were collected in triplicate from each nursery school, totalling $120 \mathrm{BT}$ samples and 120 AT samples.

The prepared samples were collected after washing the leaves individually to prepare the salad for the students. The leaves sanitized by the SNTs were packed in a plastic container, and, after mixing, 10 leaves (approximately $25 \mathrm{~g}$ ), without seasoning and salt, were removed, packed individually in polyethylene packaging, labelled, and sent in isothermal boxes with ice packs to the laboratory for the microbiological analyses.

The results were presented according to the sampling plan and the standards specified in the RDC legislation $\mathrm{N}^{\mathrm{o}} 12$ of ANVISA (Brasil, 2001). In natura lettuce samples collected from the batches distributed by the supplier were classified according to processing under Satisfactory Sanitary Conditions (SSC) or Unsatisfactory Sanitary Conditions (USC) with respect to the detection of Salmonella spp. For BT and AT $\mathrm{AC}$ and $\mathrm{DC}$ samples, examination and counting were only done for heat-tolerant coliforms, observing the most probable number (MPN), SSC, and USC.

A representative sample was considered in the microbiological sampling plan for heat-tolerant coliforms and an indicative sample, (presence/absence) for the detection of Salmonella spp.

\section{Results and discussion}

All the in natura samples were classified as samples prepared under SSC i.e., none of the samples evaluated were positive for the presence of Salmonella spp. 


\subsection{Before training}

For samples prepared for consumption before training the SNTs, it was observed that $54 \%$ of the nursery schools served lettuce salad with heat-tolerant coliform counts above the tolerance value as predicted by the legislation (Brasil, 2001), and were classified as samples prepared under USC (Table 1).

Table 1. Sanitary conditions of the prepared samples (lettuce salad) served in municipal nursery schools with respect to heat-tolerant coliforms, before training of the School Nutrition Technicians in good food handling practices.

\begin{tabular}{|ccc|}
\hline \multirow{2}{*}{ Nursery Schools } & Satisfactory Sanitary Conditions & Unsatisfactory Sanitary Conditions \\
\cline { 2 - 3 } C1 & (\% samples prepared) & (\% samples prepared) \\
C2 & 67 & 33 \\
C3 & 33 & 67 \\
C4 & - & 100 \\
C5 & - & 100 \\
C6 & 33 & 67 \\
C7 & 67 & 33 \\
C8 & 67 & 33 \\
TOTAL & 100 & - \\
\hline
\end{tabular}

All the lettuce salad samples prepared by $25 \%$ of the nursery schools were contaminated by heat-tolerant coliforms. The high rate of samples prepared under unsatisfactory sanitary conditions indicates the risk to which students are exposed.

The microbiological standards for food for human consumption in Brazil are determined by the National Agency of Sanitary Surveillance (ANVISA) through Resolution RDC No 12 (Brasil, 2001). The bacteria related to the limitations established by this legislation, almost always do not alter the appearance of the contaminated food. However, the possibility of the presence of these microorganisms in food could put consumer health at risk.

For fresh in natura vegetable samples, the analysis for the absence of Salmonella spp from the indicative sample must be carried out, according to the resolution (Brasil, 2001).

For fresh preparations of in natura vegetable samples that are peeled, fractionated, sanitized, refrigerated or frozen with the purpose of direct consumption, the analysis for the absence of Samonella spp from the indicative samples is recommended.

\subsection{After training}

After the training of the SNTs, all the salad samples collected from all the nursery schools were free of contamination by heat-tolerant coliforms and were classified as samples prepared under SSC, demonstrating the importance of training in good handling practices for food preparation in routine school practices.

According to Paruch \& Maehlum (2012) some genera of heat-tolerant coliforms are not of faecal origin. However, Escherichia coli dominates this group, and is considered as an indicator of the presence of enteropathogens in the samples.

The presence of heat-tolerant coliforms in samples prepared by $54 \%$ of the nursery schools prior to training of the school nutrition technicians in good food handling practices indicates that the sanitary conditions in these nursery schools were poor during this phase of the study, since these coliforms can easily be inactivated by the use of sanitizers (Berbari et al., 2001; Brasil, 2004).

It is possible that the presence of heat-tolerant coliforms in the lettuce samples was not only due to faecal contamination of the water used for their cultivation, but also related to contamination during transport and handling, lack of good food handling practices, improper processing and the use of utensils inadvertently 
contaminated with faecal material as well as the lack of regular training of the food handlers (Campos et al., 2009; Takayanagui et al., 2006).

Stedefeldt et al. (2013) pointed out that the main problems of FNU are related to the lack of qualification, training and continuous supervision of the servers. Training and supervision of human resources is less expensive and easier to implement than renovation and improvement of the infrastructure, since these depend heavily on hierarchical decision-making by superiors and financial investment.

Food handlers and management authorities should have adequate training in good handling practices as well as knowledge of the procedures that should be adopted by food services, with the aim of ensuring the hygiene and sanitary quality of food and compliance of food preparation with sanitary legislation. In Brazil, these practices adopted by food services were legislated by Resolution RDC N 216 of September 15, 2004 (Brasil, 2004).

Some species of heat-tolerant coliforms are highly pathogenic, and thus the students who consumed the lettuce salads prepared under USC were exposed to food poisoning (Paula et al., 2003; Passos et al., 2010). This was similar to the outbreak investigated by Passos et al. (2010), when employees of a company were affected after eating lettuce salad with cheese served at a restaurant, due to the presence of high counts of heat-tolerant coliforms originating from improper handling of the vegetables by restaurant employees.

The results corroborate the findings of Oliveira et al. (2008), Cardoso et al. (2010) and Stedefeldt et al. (2013) that food served in schools and nursery schools may carry pathogens causing gastrointestinal diseases, and that the training of food handlers in good handling practices is essential to ensure the quality and safety of prepared foods.

All handlers involved in food production need to have knowledge about hygiene, proper operational conditions and safe food preparation, by way of adequate and regular training programs that make them aware of even minimal risks to food production, proper steps to be followed during the operations, and the ideal state of health to work in; fundamentally, handlers should be supervised (Brasil, 2004). This statement is made explicit by comparing the heat-tolerant coliform counts before and after training of the school nutrition technicians in good food handling practices, demonstrating that the training and development of hygienic habits and the implementation of proper operational procedures by school nutrition technicians could reduce the contamination of lettuce salads (Brasil, 2004; Cardoso et al., 2010; Oliveira et al., 2008; Lima et al., 2013; Stedefeldt et al., 2013).

The washing of vegetables is the most frequent practice for ensuring the safety of these food products; however, good quality water must be used for washing, otherwise, it can become a primary source of contamination during the preparation of the food. The efficiency of washing, however, can be increased by the addition of antimicrobials or disinfectants to the water used for washing, thus reducing the initial microbial load that is naturally present in such food products (Berbari et al., 2001).

Considering that the washing and disinfection of lettuce were part of the training (Brasil, 2004) and represent a critical control point in an FNU (Berbari et al., 2001), both washing and disinfection can be related to the elimination of contamination in samples after the training of the school nutrition technicians.

Salmonella spp. inhabit the gastrointestinal tract of warm-blooded and cold-blooded animals, and cause faecal contamination of water and food. It can be presumed there was no risk of infection by this pathogen due to its absence in the lettuce samples (Tresseler et al., 2009).

\section{Conclusion}

The microbiological quality of the lettuce salads served in the nursery schools was considered to be unsatisfactory prior to training of the school nutrition technicians in good food handling practices. However, after training, there was no contamination, proving that the training and improvement in the sanitization and 
operational procedures could guarantee a high quality of food served to the children in nursery schools. The constant monitoring of food quality and the adoption of good practices by school FNUs is suggested.

Measures with the aim of ensuring food safety in order to meet the hygienic, sanitary and nutritional requirements were taken, and this contributed to the health, maintenance, and growth of the schoolchildren.

\section{Acknowledgements}

To the Federal Institute of Education, Science and Technology of Mato Grosso (IFMT), Cuiabá Campus - Bela Vista, for the aid given to this research; The authors are also grateful to the University of Cuiabá (UNIC), to the school meals program of the City Hall of Cuiabá-MT, to the nutrition and pharmacy scholars of the University of Cuiabá and to the food engineering scholars of the Federal Institute of Education, Science and Technology of Mato Grosso.

\section{References}

Berbari, S. A. G., Paschoalino, J. E., \& Silveira, N. S. A. (2001). Efeito do Cloro na água de lavagem para desinfecção de alface minimamente processada. Food Science and Technology, 21(2), 197-201. http://dx.doi.org/10.1590/S010120612001000200014

Brasil. Ministério da Educação. (1996). Lei no 9.394 de 20 de dezembro de 1996. Diretrizes e Bases da Educação Nacional. Estabelece as diretrizes e bases da educação nacional. Diário Oficial da União, Brasília. Retrieved in 2016, December 20, from https://www2.senado.leg.br/bdsf/bitstream/handle/id/70320/65.pdf?sequence=3

Brasil. Ministério da Saúde. (2001). Resolução RDC n 12 de 2 de janeiro de 2001. Regulamento Técnico sobre Padrões Microbiológicos para Alimentos. Portal Anvisa, Brasília. Retrieved in 2016, December 20, from http://portal.anvisa.gov.br/documents/33880/2568070/RDC_12_2001.pdf/15ffddf6-3767-4527-bfac-740a0400829b

Brasil. (2004). Resolução RDC nº 216 de 15 de setembro de 2004. Regulamento Técnico de boas práticas para serviços de alimentação. Agência Nacional de Vigilância Sanitária, Brasília. Retrieved in 2016, December 20, from http://portal.anvisa.gov.br/documents/33916/388704/RESOLU\%25C3\%2587\%25C3\%2583O-

RDC\%2BN\%2B216\%2BDE\%2B15\%2BDE\%2BSETEMBRO\%2BDE\%2B2004.pdf/23701496-925d-4d4d-99aa-9d479b316c4b

Brasil. Casa Civil. (2006). Lei $n^{\circ} 11.346$ de 15 de setembro de 2006. Cria o Sistema Nacional de Segurança Alimentar e Nutricional - SISAN com vistas em assegurar o direito humano à alimentação adequada e dá outras providências. Diário Oficial [da] República Federativa do Brasil, Brasília. Retrieved in 2016, December 20, from http://www4.planalto.gov.br/consea/conferencia/documentos/lei-de-seguranca-alimentar-e-nutricional

Brasil. Ministério da Educação. Fundo Nacional de Desenvolvimento da Educação - FNDE. (2009). Resolução/ CD/FNDE nº 38 de 16 de julho de 2009. Dispõe sobre o atendimento da alimentação escolar aos alunos da educação básica no Programa Nacional de Alimentação Escolar - PNAE. Diário Oficial da União, Brasília. Retrieved in 2016, December 20, from http://www.fnde.gov.br/fnde/legislacao/resolucoes/item/3341-resoluCao-cd-fnde-BA-38

Brasil. Ministério da Educação. Fundo Nacional de Desenvolvimento da Educação - FNDE. (2013). Resolução CD/FNDE nº 26 de 17 de junho de 2013. Dispõe sobre o atendimento da alimentação escolar aos alunos da educação básica no âmbito do Programa Nacional de Alimentação Escolar - PNAE. Fundo Nacional de Desenvolvimento da Educação, Brasília. Retrieved in 2016, December 20, from http://www.fnde.gov.br/fnde/legislacao/resolucoes/item/4620-resolu\%C3\%A7\%C3\%A3ocd-fnden\%C2\%BA-26,-de-17-de-junho-de-2013

Campos, A. K. C., Cardonha, Â. M. S., Pinheiro, L. B. G., Ferreira, N. R., Azevedo, P. M. R., \& Stamford, T. L. M. (2009). Assessment of personal hygiene and practices of food handlers in municipal public schools of Natal, Brazil. Food Control, 20(9), 807-810. http://dx.doi.org/10.1016/j.foodcont.2008.10.010

Cardoso, R. C. V., Almeida, R. C. C., Guimaraes, A. G., Goes, J. A. W., Santana, A. A. C., Silva, S. A., Vidal Junior, P. O., Huttner, L. B., \& Figueiredo, K. V. N. A. (2010). Avaliação da qualidade microbiológica de alimentos prontos para consumo servidos em escolas atendidas pelo Programa Nacional de Alimentação Escolar. Revista do Instituto Adolfo Lutz, 69(2), 208213.

Cho, H. O., \& Bae, H. J. (2016). Effect of foodservice employee's hand hygiene improvement according to food safety education. Journal of the Korean Society of Food Science and Nutrition, 45(2), 284-292. http://dx.doi.org/10.3746/jkfn.2016.45.2.284

Cuiabá. Prefeitura Municipal. (2010). Composição dos Bairros de Cuiabá - Data base dezembro de 2009. Cuiaba: Instituto de Planejamento e Desenvolvimento Urbano. Retrieved in 2016, December 20, from http://www.cuiaba.mt.gov.br/upload/arquivo/composicao_bairros.pdf

Cunha, D. T., Stedefeldt, E., \& Rosso, V. V. (2012). Perceived risk of foodborne disease by school food handlers and principals: the importance of frequent training. Journal of Food Safety, 32(2), 219-225. http://dx.doi.org/10.1111/j.1745-4565.2012.00371.x

Egan, M. B., Raats, M. M., Grubb, S. M., Eves, A., Lumbers, M. L., Dean, M. S., \& Adams, M. R. (2007). A review of food safety and food hygiene training studies in the commercial sector. Food Control, 18(10), 1180-1190.

http://dx.doi.org/10.1016/j.foodcont.2006.08.001 
Elias, S. O., Decol, L. T., \& Tondo, E. C. (2018). Foodborne outbreaks in Brazil associated with fruits and vegetables: 2008 through 2014. Food Quality and Safety, 2(4), 173-181. http://dx.doi.org/10.1093/fqsafe/fyy022

Falomir, M. P., Gozalbo, D., \& Rico, H. (2010). Coliform bacteria in fresh vegetables: from cultivated lands to consumers. In A. Méndez-Vilas (Ed.), Current research, technology and education topics in applied microbiology and microbial biotechnology ( $\mathrm{pp}$. 1175-1181). Badajoz: Formatex Research Center.

Fundo Nacional do Desenvolvimento da Educação - FNDE. (2014). Programa Nacional de Alimentação Escolar - Dados estatísticos. Retrieved in 2016, December 20, from http://www.fnde.gov.br/programas/alimentacao-escolar/alimentacao-escolarconsultas/alimentacao-escolar-dados-estatisticos/

Fundo Nacional do Desenvolvimento da Educação - FNDE. (2015). Programa Nacional de Alimentação Escolar - Consultas: alunado por ação do Programa Nacional de Alimentação Escolar. Retrieved in 2016, December 20, from https://www.fnde.gov.br/pnaeweb/publico/relatorioDelegacaoEstadual.do

Henz, G. P., \& Suinaga, F. (2009). Tipos de alface cultivados no Brasil (Comunicado Técnico, no. 75). Brasília: Embrapa. Retrieved in 2016, December 20, from http://www.cnph.embrapa.br/paginas/serie_documentos/publicacoes2009/cot_75.pdf/

Lima, A. F. A., Cunha, D. T., \& Stedefeld, E. (2013). Avaliação do risco sanitário em unidades de alimentação e nutrição escolar da baixada santista, SP. Higiene Alimentar, 27(218-219), 51-56.

Neitzke, D. C., Roza, C. R., \& Weber, F. H. (2017). Segurança dos alimentos: contaminação por Salmonella sp. no abate de suínos. Brazilian Journal of Food Technology, 20, e2015063.

Oliveira, M. N., Brasil, A. L. D., \& Taddei, J. A. A. C. (2008). Avaliação das condições higiênico-sanitárias das cozinhas de creches públicas e filantrópicas. Ciencia \& Saude Coletiva, 13(3), 1051-1060. PMid:18813599. http://dx.doi.org/10.1590/S141381232008000300028

Öz, V., Karadayi, S., Çakan, H., Karadayi, B., \& Çevik, F. E. (2014). Assessment of microbiological quality of ready-to-eat foods in Istanbul, Turkey. Journal of Food Agriculture and Environment, 12(3-4), 56-60.

Paruch, A. M., \& Maehlum, T. (2012). Specific features of Escherichia coli that distinguish it from coliform and thermotolerant coliform bacteria and define it as the most accurate indicator of faecal contamination in the environment. Ecological Indicators, 23, 140-142. http://dx.doi.org/10.1016/j.ecolind.2012.03.026

Passos, E. D. C., Mello, A. R. P. D., Sousa, C. V. D., Silva, C. R. D., Alonso, A. C. B., Gonzalez, E., \& Tavares, M. (2010). Provável surto de toxinfecção alimentar em funcionários de uma empresa no litoral da região sudeste do Brasil. Revista do Instituto Adolfo Lutz, 69(1), 136-140.

Paula, P., Rodrigues, P. S. S., Tortora, J. C. O., Uchoa, C. M. A., \& Farage, S. (2003). Contaminação microbiológica e parasitológica em alfaces (Lactuca sativa) de restaurantes self-service, de Niterói, RJ. Revista da Sociedade Brasileira de Medicina Tropical, 36(4), 535-537. PMid:12937736. http://dx.doi.org/10.1590/S0037-86822003000400019

Raphaelli, C. O., Passos, L. D. F., Couto, S. F., Helbig, E., \& Madruga, S. W. (2017). Adesão e aceitabilidade de cardápios da alimentação escolar do ensino fundamental de escolas de zona rural. Brazilian Journal of Food Technology, 20, e2016112. http://dx.doi.org/10.1590/1981-6723.11216

Röhr, A., Lüddecke, K., Drusch, S., Müller, M. J., \& Alvensleben, R. V. (2005). Food quality and safety - consumer perception and public health concern. Food Control, 16(8), 649-655. http://dx.doi.org/10.1016/j.foodcont.2004.06.001

Santana, L. R. R., Carvalho, R. D. S., Leite, C. C., Alcantara, L. M., Oliveira, T. W. S., \& Rodrigues, B. M. (2006). Qualidade física, microbiológica e parasitológica de alfaces (Lactuca sativa) de diferentes sistemas de cultivo. Food Science and Technology (Campinas), 26(2), 264-269. http://dx.doi.org/10.1590/S0101-20612006000200006

Santana, N. G., Almeida, R. C. C., Ferreira, J. S., \& Almeida, P. F. (2009). Microbiological quality and safety of meals served to children and adoption of good manufacturing practices in public school catering in Brazil. Food Control, 20(3), 255-261. http://dx.doi.org/10.1016/j.foodcont.2008.05.004

Santos, Y. O., Almeida, R. C. C., Guimarães, A. G., \& Almeida, P. F. (2010). Hygienic-sanitary quality of vegetables and evaluation of treatments for the elimination of indigenous $E$. coli and $E$. coli $\mathrm{O} 157: \mathrm{H} 7$ from the surface of leaves of lettuce (Lactuca sativa L.). Food Science and Technology (Campinas), 30(4), 1083-1089. http://dx.doi.org/10.1590/S010120612010000400038

Stedefeldt, E., Cunha, D. T., Silva Júnior, E. A., Silva, S. M., \& Oliveira, A. B. A. (2013). Instrumento de avaliação das boas práticas em unidades de alimentação e nutrição escolar: da concepção à validação. Ciencia \& Saude Coletiva, 18(4), 947-953. PMid:23670370. http://dx.doi.org/10.1590/S1413-81232013000400006

Takayanagui, O. M., Capuano, D. M., Oliveira, C. A. D., Bergamini, A. M. M., Okino, M. H. T., Castro e Silva, A. A., Oliveira, M. A., Ribeiro, E. G., \& Takayanagui, A. M. (2006). Análise da cadeia de produção de verduras em Ribeirão Preto, SP. Revista da Sociedade Brasileira de Medicina Tropical, 39(2), 224-226. PMid:16699655. http://dx.doi.org/10.1590/S003786822006000200018 
Tresseler, J. F. M., Figueiredo, E. A. T., Figueiredo, R. W., Machado, T. F., Delfino, C. M., \& Sousa, P. H. M. (2009). Avaliação da qualidade microbiológica de hortaliças minimamente processadas. Ciência e Agrotecnologia, 33(spe), 1722-1727. http://dx.doi.org/10.1590/S1413-70542009000700004

Veiros, M. B., Proença, R. P. C., Santos, M. C. T., Kent-Smith, L., \& Rocha, A. (2009). Food safety practices in a Portuguese canteen. Food Control, 20(10), 936-941. http://dx.doi.org/10.1016/j.foodcont.2009.02.002

Funding: Instituto Federal de Educação, Ciência e Tecnologia de Mato Grosso/IFMT e CAPES.

Received: Oct. 25, 2018; Approved: Feb. 05, 2019. 